\title{
Erratum to: Application of landslide hazard scenarios at annual scale in the Niraj River basin (Transylvania Depression, Romania)
}

\author{
Roşca Sanda • Bilaşco Ştefan • Petrea Dănuţ • Fodorean Ioan • \\ Vescan Iuliu • Filip Sorin
}

Published online: 5 March 2015

(C) Springer Science+Business Media Dordrecht 2015

\section{Erratum to: Nat Hazards DOI 10.1007/s11069-015-1665-2}

Acknowledgments This paper is prepared and published under the aegis of the Research Institute for Quality of Life, Romanian Academy, as a part of programme co-funded by the European Union within the Operational Sectorial Programme for Human Resources Development through the project for Pluri and interdisciplinary in doctoral and postdoctoral programmes Project Code: POSDRU/159/1.5/S/141086.

The online version of the original article can be found under doi:10.1007/s11069-015-1665-2.

R. Sanda $(\varangle) \cdot$ B. Ştefan · P. Dănuţ · F. Ioan · V. Iuliu · F. Sorin

Faculty of Geography, Babeş-Bolyai University, 400006 Cluj-Napoca, Romania

e-mail: rosca_sanda@yahoo.com

B. Ştefan

e-mail: sbilasco@geografie.ubbcluj.ro

P. Dănuţ

e-mail: dpetrea@geografie.ubbcluj.ro

F. Ioan

e-mail: fioan@geografie.ubbcuj.ro

V. Iuliu

e-mail: vescan@geografie.ubbcluj.ro

F. Sorin

e-mail: sfilip@geografie.ubbcluj.ro

B. Ştefan

Romanian Academy, Cluj-Napoca Subsidiary Geography Section, 9, Republicii Street, 400015 Cluj-Napoca, Romania 